\title{
A Review of Water Quality Indices Used to Assess the Health Status of High Mountain Wetlands
}

\author{
María Custodio \\ Universidad Nacional del Centro del Perú, Av. Mariscal Castilla, Huancayo, Perú \\ Email: mcustodio@uncp.edu.pe
}

How to cite this paper: Custodio, M. (2019) A Review of Water Quality Indices Used to Assess the Health Status of High Mountain Wetlands. Open Journal of Ecology, 9, 66-83.

https://doi.org/10.4236/oje.2019.93007

Received: February 16, 2019

Accepted: March 23, 2019

Published: March 26, 2019

Copyright $\odot 2019$ by author(s) and Scientific Research Publishing Inc. This work is licensed under the Creative Commons Attribution International License (CC BY 4.0). http://creativecommons.org/licenses/by/4.0/

\begin{abstract}
The health status of wetlands depends to a large extent on the permanence and quality of water. However, natural and anthropogenic pressures on these ecosystems are transforming them and driving them to generate timely and reliable information. The aim of this study is to provide a review of water quality indices used to assess the health status of high mountain wetlands. To this end, an exhaustive search was initially carried out for studies with significant contributions to the knowledge of high mountain wetlands in Peru. In total, 90 articles on wetlands published in the last decade (2007-2017) were reviewed through bibliographic managers, of which $25 \%$ corresponded to wetland studies in Peru and of these only $6 \%$ to water quality in high Andean wetlands.
\end{abstract}

\section{Keywords}

Water Quality, Biotic Indices, Diversity Indices, Conventional Indices, Sustainable Management

\section{Introduction}

Livelihoods in developing countries are highly dependent on intact and functioning wetlands. Permanency and water quality have been identified as factors that affect the structure and composition of biological communities [1]; as well as the services provided by these ecosystems (groundwater recharge, flood water retention, static baseflow contributions, biogeochemical processing, improved water quality and wildlife habitat) [2]. However, these factors responsible for maintaining the integrity of aquatic ecosystems are strongly influenced by pop- 
ulation growth, urbanization, land-use change, hydrological-climatic changes and traditional practices [3] [4].

Studies on the overall extent of wetlands, especially in South Asia and South America, show that wetlands have declined by 6\% in just 14 years (de 1993 a 2007) due to continued and disorderly urban growth [5]. These changes have generated in recent decades the need to better assess and manage the cumulative effects of human interventions on wetlands [6] [7] [8] [9]. The use of biological communities to assess the ecological status of water bodies has become a major component of water-related legislation worldwide [10] [11], as they provide a quantifiable response to various environmental disturbances [12].

High Andean wetlands are an integral part of the landscape as they provide habitat for a diversity of plants and animals. They also act as buffers for floods and erosion, and serve as key links in the global water and biogeochemical cycles [13]. Although it is difficult to measure the state they are in, a healthy wetland must generally demonstrate good water quality and functioning [14]. In other words, a healthy wetland should not show signs of stress related to substantial degradation or cumulative effects of minor degradation, and should be exempt from modifications that restrict the flow of water into or out of the wetland, or that alter seasonality patterns.

In particular, there is a need to address the value of the high Andean wetlands as a "sink" for many chemicals, including atmospheric carbon, and other key functions they perform. However, these high Andean water ecosystems are still the least studied and one of the most threatened ecosystems. The decline in water quality in these ecosystems comes mainly from inadequate management, although they play a fundamental role in human well-being and the global importance they have in maintaining ecological balance. In this regard, the aim of this study is to provide a review of the indices for assessing anthropogenic impact in water quality in high Andean wetlands.

\section{Organization and Method of Study}

The study is divided into five sections. In the first section, a summary of the current status of the high Andean wetlands is provided. The second section emphasizes anthropogenic pressures on water quality. The third section presents the physico-chemical or conventional index. In the fourth and fifth sections, the biotic and multicriterio indices are presented, respectively. For it, an exhaustive search was initially carried out for studies with significant contributions to knowledge of the high Andean wetlands. Then, and considering that the good health status of wetlands depends to a large extent on the permanence and quality of water, we proceeded to identify studies aimed at assessing the health status of these ecosystems and the indices that determine it. In total, 90 articles on wetlands published in the last decade (2007-2017) were reviewed through bibliographic managers, of which $25 \%$ corresponded to wetland studies in Peru and of these only $6 \%$ to water quality in high Andean wetlands (Table 1). 
Table 1. List of studies carried out in wetlands of Peru, by zone, region and thematic axis.

\begin{tabular}{cccc}
\hline Zone & Region & Thematic axis & Reference \\
\hline \multirow{3}{*}{ North } & Water & {$[15][16][17][18]$} \\
& & Plants & {$[19]$} \\
& Fauna & {$[20]$} \\
& & Water & {$[21][22]$} \\
& Coast & Plants & {$[23][24][25]$} \\
& & Zooplankton & {$[26][27][28]$} \\
Center & Fauna & {$[29][30]$} \\
& & Water & {$[22]$} \\
& Sierra & Plants & {$[23]$} \\
& Forest & Plants & {$[24]$} \\
& Costa & Fauna & {$[25]$} \\
& Sierra & Water & {$[26]$} \\
& & Plants & {$[26][27]$} \\
& & Fauna & {$[29]$} \\
& & Climate &
\end{tabular}

\section{Current Status of the High Andean Wetlands}

The high Andean wetlands, located at an altitude of 3300 meters above sea level, are shallow water ecosystems associated with streams, rivers, lagoon edges, springs and thaw waters that harbor characteristic biological communities, have a permanent or temporary water regime and are considered fragile ecosystems under natural and anthropogenic pressure [30].

The historical data on the health status of the high Andean wetlands is rudimentary, as there is no real estimate of the area of wetlands in good conservation status and how many have been lost. Despite the efforts of the state entities with environmental competence to generate cartographic information on vegetation cover in Peru [31] and many researchers from the Andean region that have projected changes in precipitation and temperature behavior, hydrology and climatology studies in these ecosystems are scarce [32]. This paucity of information makes it difficult to understand the potential impacts of anthropogenic activities and climate change (Figure 1).

Water pollution in the high Andean wetlands is a major threat to species with restricted geographic ranges and narrow ecological niches, plant and animal endemism in the eastern Andean slope: Challenges to conservation [33] [34] [35]. Also, water transfer works to the coast that increases the risk of loss of high Andean wetlands [36] [37]. Consequently, as the wetland area is lost, key functions of these ecosystems are lost, among which stand out for their importance and global value: supporting biodiversity, improving water quality, reducing flooding and sequestering carbon. 


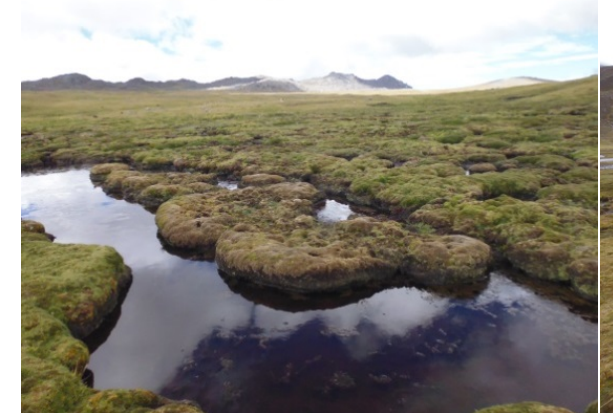

(a)

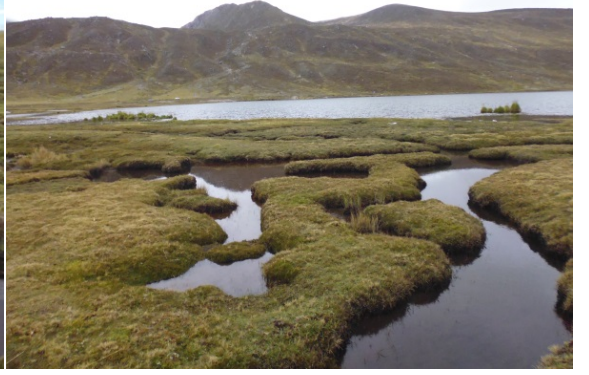

(b)

Figure 1. High Andean wetlands of the Junin Region. (a) Area with typical vegetation covers (Distichia muscoides y Oxychloe andina), (b) ponds associated with lagoon.

\section{Anthropogenic Impact on Water Quality}

Inland aquatic ecosystems around the world are undergoing changes in quality, quantity and biodiversity due to pollution by different types of pollutants such as fertilizers, wastewater and heavy metals resulting from the development of anthropogenic activities [38]. The increase in these activities is putting strong pressure on this resource and interfering with vital and legitimate uses of water at the local, regional or international level [39] [40]. The overexploitation and pollution of water, as well as the degradation of aquatic ecosystems, are having a direct impact on the well-being of populations that depend on these ecosystems for their livelihoods.

The high Andean wetlands are ecosystems of great ecological value, with a rich fauna consisting of communities with a complex structure and high biological value. However, their special typology makes them fragile and vulnerable to environmental changes, especially those related to anthropogenic disturbances, which often involve irreversible degradation of their biota [41] [42]. The vulnerability of these habitats is also evident in relation to the potential impacts of climate change. One of the predictable effects could be that some of these systems will change from permanent to seasonal and some will even disappear. As a result, the biodiversity of many of them will be reduced and their biogeochemical cycles altered [43].

\section{Water Quality Indices}

The constant battle to develop the most appropriate method for assessing water quality in aquatic systems has allowed indicators to be integrated into indices that reveal more accurate information regarding their state. Water quality indices aim at giving a single value to the water quality of a source reducing great amount of parameters into a simpler expression and enabling easy interpretation of monitoring data. Classically, physico-chemical indicators have been used to evaluate the entry, distribution and dispersion of chemical agents in the aquatic environment and their assimilation into living tissues [44]. However, when pollutants enter sporadically these indicators are no longer of choice, as they are 
only an instantaneous reflection of the environmental condition. In contrast, indicators based on biological communities allow for temporal integration and reveal a current or past effect of anthropogenic disturbances. Thus, water pollution control has become a key element of effective policies to prevent, control and reduce the content of dangerous substances, nutrients and other water pollutants from point sources in aquatic ecosystems.

\subsection{Physical-Chemical or Conventional Indices}

These indices are based on the integration of different physico-chemical indicators to provide a global vision of water quality. The values of physico-chemical indices can vary from 0 (very poor quality) to 100 (excellent quality). At a global level, different indices have been developed, including the WQI of the National Sanitation Foundation of the United States (WQI-NSF), which has been validated and adapted in different countries, and the WQI of Dinius [45], which, unlike the WQI-NSF, which is oriented towards waters to be used for human consumption, considers five uses of water (human consumption, agriculture, fishing and aquatic, industrial and recreational life) [46]. Other indices proposed in the last decade are: WQI of raw water for public supply-IAP of Brazil; calculated from the WQI of NSF and the toxic substance index-ISTO (CETESB 2006), the Universal Water Quality Index U-WQI consisting of 11 physico-chemical indicators and a bacteriological [47] based on European Union Directives, and the Drinking Water Quality Index-DWQI developed to assess the global situation of water collection sources [48] (Table 2).

\subsection{National Sanitation Foundation's Water Quality Index (NSF-WQI)}

Brown et al. [49] developed a water quality index similar in structure to the Horton index but much more rigorously in the selection of indicators, developing a common scale and assigning weights for which Delphic exercises were developed. This effort was supported by the National Sanitation Foundation (NSF). For this reason, the Brown index is also known as NSF-WQI [50]. However, in the course of using the index, it was found that the arithmetic or additive formulation, while easy to understand and calculate, lacked sensitivity in terms of the effect that a single bad parameter value would have on the WQI. This led to Brown et al. [51] to propose a variation of NSF-WQI, a multiplicative formulation.

\subsection{Dinius' Second Index}

A multiplicative water-quality index was developed by Dinius with liberal use of Delphi in decision making [52]. The index included 12 pollutants e dissolved oxygen, $\mathrm{BOD}_{5}$, coliform count, E. coli, $\mathrm{pH}$, alkalinity, hardness, chloride, specific conductivity, temperature, colour and nitrate e for six water uses e public water supply, recreation, fish, shellfish, agriculture and industry. The sub index functions 
Table 2. Equations for the calculation of global water quality indices considering physical, chemical and biological indicators.

\begin{tabular}{|c|c|c|c|}
\hline Grupo & Índice & Ecuación/Descripción & Indicators \\
\hline \multirow{4}{*}{1} & $\begin{array}{l}\text { NSF-WQI } \\
\text { (EU) } \\
\text { (Brown et al. } \\
\text { 1970) }\end{array}$ & $\begin{array}{l}\qquad \text { NSF-WQI }=\sum_{i=1}^{9} S I_{i} * W_{i} \\
\text { SNF-WQI: Water quality index according to } \\
\text { the U.S. National Sanitation Foundation; a } \\
\text { number between } 0 \text { and } 100 \\
S I_{i}: \text { Quality of the i-th parameter. A number } \\
\text { between } 0 \text { and } 100 \text {; depending on } \\
\text { concentration or measurement (analysis } \\
\text { result). } \\
W_{i}: \text { Weight corresponding to the i-th } \\
\text { parameter set according to its importance } \\
\text { for the overall conformation of quality; it is } \\
\text { a number between } 0 \text { and } 1 .\end{array}$ & $\begin{array}{c}\text { Temperature, } \mathrm{pH} \text {, } \\
\text { dissolved oxygen, } \\
\text { biological oxygen } \\
\text { demand, turbidity, } \\
\text { total solids, faecal } \\
\text { coliforms, nitrates } \\
\text { and total } \\
\text { phosphates }\end{array}$ \\
\hline & $\begin{array}{l}\text { Dinius-WQI } \\
\quad(\mathrm{EU}) \\
\text { (Dinius 1987) }\end{array}$ & $\begin{array}{l}\qquad I=\sum_{i=1}^{11} W_{i} * I_{i} \\
I_{i}: \text { Variable sub-index } \\
W_{i}: \text { Weighted weight for sub-index i. }\end{array}$ & $\begin{array}{c}\text { Temperature, } \mathrm{pH} \text {, } \\
\text { dissolved oxygen, } \\
\text { biological oxygen } \\
\text { demand, nitrates, } \\
\text { colour, } \\
\text { conductivity, } \\
\text { alkalinity, hardness, } \\
\text { chlorides, total } \\
\text { coliforms and } \\
\text { faecal coliforms. }\end{array}$ \\
\hline & $\begin{array}{l}\text { CETESB-WQI } \\
\text { (Brasil) } \\
\text { Rojas-WQI } \\
\text { (Colombia) }\end{array}$ & $\begin{array}{l}\qquad \mathrm{WQI}=\prod_{i=1}^{n} I_{i}^{W_{i}} \\
W_{i} \text { : Weight or percentage assigned to the } \\
\text { i-th parameter } \\
I_{i} \text { : Sub-index of i-th parameter. }\end{array}$ & $\begin{array}{c}\text { Temperature, } \mathrm{pH}, \\
\text { dissolved oxygen, } \\
\text { biological oxygen } \\
\text { demand, turbidity, } \\
\text { dissolved total } \\
\text { solids, faecal } \\
\text { coliforms, total } \\
\text { phosphorus and } \\
\text { total nitrogen. }\end{array}$ \\
\hline & $\begin{array}{l}\text { CCME-WQI } \\
\text { (Canadá) } \\
\text { DWQI (EU) }\end{array}$ & $\begin{array}{l}\text { CCMEWQI }=100-\left[\frac{\sqrt{\left(F_{1}\right)^{2}+\left(F_{2}\right)^{2}+\left(F_{3}\right)^{2}}}{1.732}\right] \\
\text { Scope }\left(F_{1}\right) \text { : Percentage of parameters that } \\
\text { exceed the standard. } \\
\text { Frequency }\left(F_{2}\right) \text { : Percentage of individual } \\
\text { tests for each parameter that exceeds the } \\
\text { standard. } \\
\text { Amplitude }\left(F_{3}\right) \text { : magnitude by which each } \\
\text { parameter that does not comply exceeds the } \\
\text { norm. }\end{array}$ & $\begin{array}{l}F_{1} \\
F_{2} \\
F_{3}\end{array}$ \\
\hline 3 & $\begin{array}{l}\text { U-WQI } \\
\text { (Europa) } \\
\text { (Boyacioglu } \\
\text { 2007) }\end{array}$ & $\begin{array}{l}\qquad \mathrm{UWQI}=\sum_{i=1}^{n} W_{i} I_{i} \\
W_{i} \text { : weight or percentage assigned to the } \mathrm{i} \text {-th } \\
\text { parameter } \\
I_{i}: \text { i-th parameter sub-index. }\end{array}$ & $\begin{array}{l}\text { Cadmium, cyanide, } \\
\text { mercury, selenium, } \\
\text { arsenic, fluoride, } \\
\text { nitrate-nitrogen, } \\
\text { DO, } \mathrm{BOD}_{5} \text {, total } \\
\text { phosphorus, } \mathrm{pH} \\
\text { and total coliform. }\end{array}$ \\
\hline
\end{tabular}


were worked out as summarized in Table 3.

\subsection{A Universal Water-Quality Index (U-WQI)}

Boyacioglu, took into consideration the water-quality standards set by the Council of European Communities [53], the Turkish water pollution control regulations and other scientific information to select 12 water-quality parameters as the most representative for drinking water quality. They set three classes of water e representing "excellent", "acceptable" and "polluted" categories (Table 4).

Table 3. Qualifications and weights by parameter included in the INSF water quality index.

\begin{tabular}{|c|c|c|c|}
\hline Parameters & Dimension & Weight & Function \\
\hline Dissolved oxygen & $\%$ saturation & 0.109 & $0.82 \mathrm{DO}+10.56$ \\
\hline $\mathrm{BOD}_{5}$ & $\mathrm{mg} / \mathrm{L}$, at $20^{\circ} \mathrm{C}$ & 0.097 & $108(\mathrm{BOD})^{-0.3494}$ \\
\hline Coliform & NMP-Coli/100 ml & 0.090 & $136(\mathrm{COLI})^{-0.1311}$ \\
\hline E. coli & Faecal-Coli/100 ml & 0.116 & $106(\mathrm{E}-\mathrm{COLI})^{-0.1286}$ \\
\hline Alkalinity & ppm $\mathrm{CaCO}_{3}$ & 0.063 & $110(\mathrm{ALK})^{-0.1342}$ \\
\hline Hardness & ppm $\mathrm{CaCO}_{3}$ & 0.065 & $552(\mathrm{HA})^{-0.4488}$ \\
\hline Chloride & $\mathrm{Mg} / \mathrm{L}$, fresh water & 0.074 & $391(\mathrm{CL})^{-3480}$ \\
\hline Sp. Conductance & $\mu \mathrm{mhos} / \mathrm{cm} 25^{\circ} \mathrm{C}$ & 0.079 & $506(\mathrm{SPC})^{-0.3315}$ \\
\hline $\mathrm{pH}$ & $\begin{array}{c}\mathrm{pH}<6.9 \\
\text { pH-units }(6.9-7.1) \\
\mathrm{pH}>7.1\end{array}$ & 0.077 & $\begin{array}{c}10^{0.6803+0.1856(\mathrm{pH})} \\
1 \\
10^{3.65-0.2216(\mathrm{pH})}\end{array}$ \\
\hline Nitrate & As $\mathrm{NO}_{3}, \mathrm{mg} / \mathrm{L}$ & 0.090 & $125(\mathrm{~N})^{-0.2718}$ \\
\hline Temperature & ${ }^{\circ} \mathrm{C}$ & 0.077 & $10^{2.004-0.0382_{\left(\mathrm{T}_{\mathrm{a}}-\mathrm{T}_{\mathrm{s}}\right)}}$ \\
\hline Colour & Colour units-Pt std & 0.063 & $127(\mathrm{C})^{0.2394}$ \\
\hline
\end{tabular}

Table 4. Significance ratings and weights assigned to different parameters in the U-WQI of Boyacioglu.

\begin{tabular}{cccc}
\hline Category & Parameters & Rating & Weight Factor \\
\hline Health hazard & Total coliform & 4 & 0.114 \\
& Cadmium & 3 & 0.086 \\
& Cyanide & 3 & 0.086 \\
& Mercury & 3 & 0.086 \\
& Selenium & 3 & 0.086 \\
& Arsenic & 4 & 0.113 \\
Operational & Fluoride & 3 & 0.086 \\
Monitoring & Nitrate-nitrogen & 3 & 0.086 \\
Oxygen & Dissolved oxygen & 4 & 0.114 \\
Depletion & pH & 1 & 0.029 \\
& BOD & 2 & 0.057
\end{tabular}




\subsection{The Canadian Council of Ministers of Environment Water Quality Index (CCME-WQI)}

The CCME-WQI is an adaptation of the BCWQI, which consists of three factors, each of which has been scaled between 0 and 100. In the CCME-WQI, the values of the three variance measures of the selected objectives for water quality are combined to create a vector in an imaginary space of "objective exceedance". In the index, "objectives" refer to water quality guidelines across Canada or site-specific water quality objectives [54]. The length of the vector is then scaled to range between 0 and 100, and subtracted from 100 to produce an index which is 0 (or close to 0 ) for very poor water quality, and close to 100 for excellent water quality. The CCME-WQI consists of three factors as shown in Figure 2.

Factor $1\left(F_{1}\right)$ Scope: This factor is called scope because it assesses the extent of the noncompliance of water-quality guideline over the period of interest.

$$
F_{1}=\left(\frac{\text { Number of failed variables }}{\text { Total number of variables }}\right) \times 100
$$

where variables indicate those water-quality parameters with objectives which were tested during the time period for the index calculation.

Factor $2\left(F_{2}\right)$ Frequency: It represents the percentage of individual tests that do not meet the objectives ("failed tests"):

$$
F_{2}=\left(\frac{\text { Number of failed tests }}{\text { Total number of tests }}\right) \times 100
$$

Factor $3\left(F_{3}\right)$ Amplitude: It represents the amount by which the failed test values do not meet their objectives, and is calculated in three steps:

1) The number of times by which an individual concentration is greater than (or less than, when the objective is a minimum) the objective is termed an "excursion" and is expressed as follows. When the test value must not exceed the objective.

$$
\text { Excursion }_{i}=\left(\frac{\text { Failed Test Value }_{i}}{\text { Objective }_{j}}\right)-1
$$

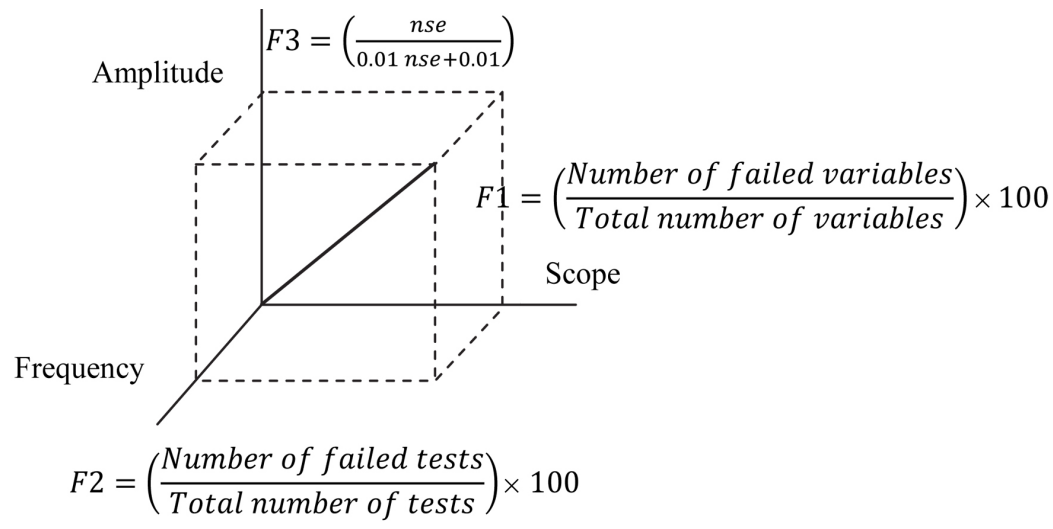

Figure 2. Three-dimensional representation of the water quality index by adding three factors $\left(F_{1}, F_{2}\right.$ and $\left.F_{3}\right)$ as vectors [55]. 
For the cases in which the test value must not fall below the objective:

$$
\text { Excursion }_{i}=\left(\frac{\text { Objective }_{j}}{\text { Failed Test Value }_{i}}\right)-1
$$

2) The total extent by which individual tests fail to comply is calculated by summing the excursions of individual tests from their objectives and dividing by the total number of tests (those which do and do not meet their objectives). This variable, referred to as the normalised sum of excursions, or nse, is calculated as:

$$
n s e=\frac{\sum_{i=1}^{n} \text { excursion }_{i}}{\text { \# of tests }}
$$

3) $F_{3}$ is then calculated by an asymptotic function that scales the normalised sum of the excursions from objectives (nse) to yield a range between 0 and 100:

$$
F_{3}=\left(\frac{n s e}{0.01 n s e+0.01}\right)
$$

The CCME-WQI is finally calculated as:

$$
\text { CCM-EWQI }=100-\left[\frac{\sqrt{\left(F_{1}\right)^{2}+\left(F_{2}\right)^{2}+\left(F_{3}\right)^{2}}}{1.732}\right]
$$

The factor of 1.732 arises because each of the three individual index factors can range as high as 100 . This means that the vector length can reach $\sqrt{100^{2}+100^{2}+100^{2}}=\sqrt{30000}=173.2$ as a maximum. Division by 1.732 brings the vector length down to 100 as a maximum. It may be seen that the CCME-WQI is closely related to the BCWQI which, in turn, has been found to be extremely sensitive to sampling design and on the chosen water-quality objective [56].

\section{Biotic Indices}

The concept of the Water Quality Index (WQI) was introduced in its rudimentary form more than a century ago when the presence or absence of certain organisms in a water source was used as an indicator of the stressful forces of human activities [57] [58]. The first WQI in history was therefore a "biotic" index (Figure 3).

Biotic indices are more "expressive" and revealing of ecological health. In biotic indices, each taxon from a particular group of organisms is assigned a sensitivity weighting, or a "score", based on the tolerance or sensitivity of that taxon to particular pollutants [59] [60]. The scores of all the individual taxa sampled at a site are summed and/or averaged to provide a value by which the ecological health of the biotic community, hence the health of the water body, can be gauged [61]. Some biotic indices include abundance estimates in the scoring system [62].

\subsection{Biotic Indices Based on Macroinvertebrates}

There are several advantages in using benthic macroinvertebrates in bioassess- 
ment [63] [64].

Benthic macroinvertebrates are largely nonmobile, ubiquitous and relatively abundant inhabitants of both lotic and lentic habitats. There are often many species within a community with varying sensitivities to stresses and relatively quick reaction times, resulting in a spectrum of graded, recognizable responses to environmental perturbations [65]. Also, responses to different types of pollution have been established for many common species. Macroinvertebrates have life cycles that are long enough for temporal changes caused by perturbations to be detected, but short enough to enable the observation of decolonization patterns following perturbation [66]. They are relatively easy and inexpensive to collect, particularly if qualitative sampling is undertaken, and are well suited to the experiments required for biomonitoring. Studies have shown that the issue of variability in the types of habitats of macroinvertebrates within a water body can be easily resolved by pooling of samples [67] [68].

\subsection{Biological Monitoring Working Party (BMWP) Score System}

In this system, which was introduced in 1978 and modified in 1980 and 1983, all major aquatic habitat types are sampled with a pond net of $90 \mathrm{~mm}$ mesh size for a total of $3 \mathrm{~min}$ and taxa are identified in the field. The score values for all the predefined invertebrate families present in the sample for a site are summed to give the Total BMWP Score [69] [70] [71] [72]. The value ranges from less than 16 for severely polluted waters to more than 120 where very clean water indicator families can be found (Table 5). There are many global adaptations of this index, including the one adapted by Custodio and Amésquita (BMWP-PeA) [73] to evaluate high Andean lotic systems, which considers values ranging from less than 15 to more than 120 .

\section{Multimetric Indices Based on Environmental Indicators}

DPSIR represents the feedback loop system seen to operate everywhere in which driving forces (D) of social and economic development exert pressure $(\mathrm{P})$ on the environment, thereby stressing it and changing its state (S), potentially resulting in impacts (I) on human health and/or ecosystem function [74] [75]. These, then, elicit an environmental management response (R) (Figure 4). More often

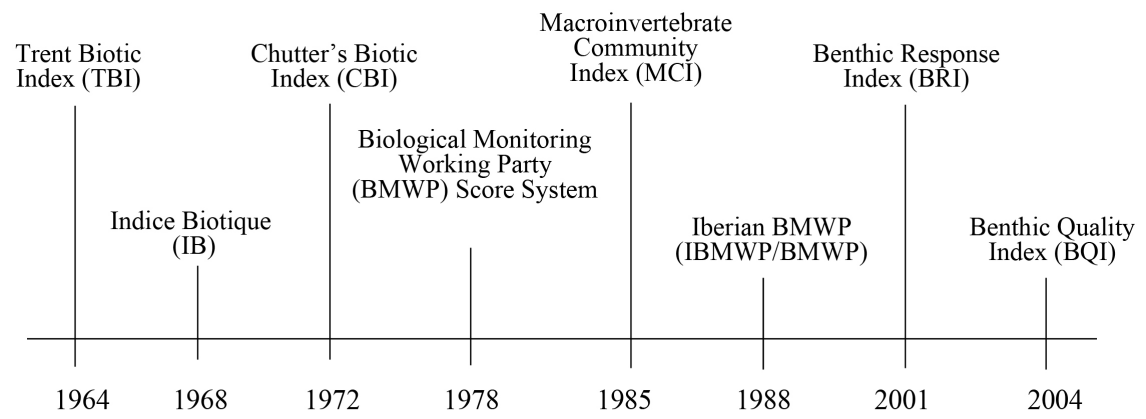

Figure 3. Evolution of the development of biotic indices at a global level. 


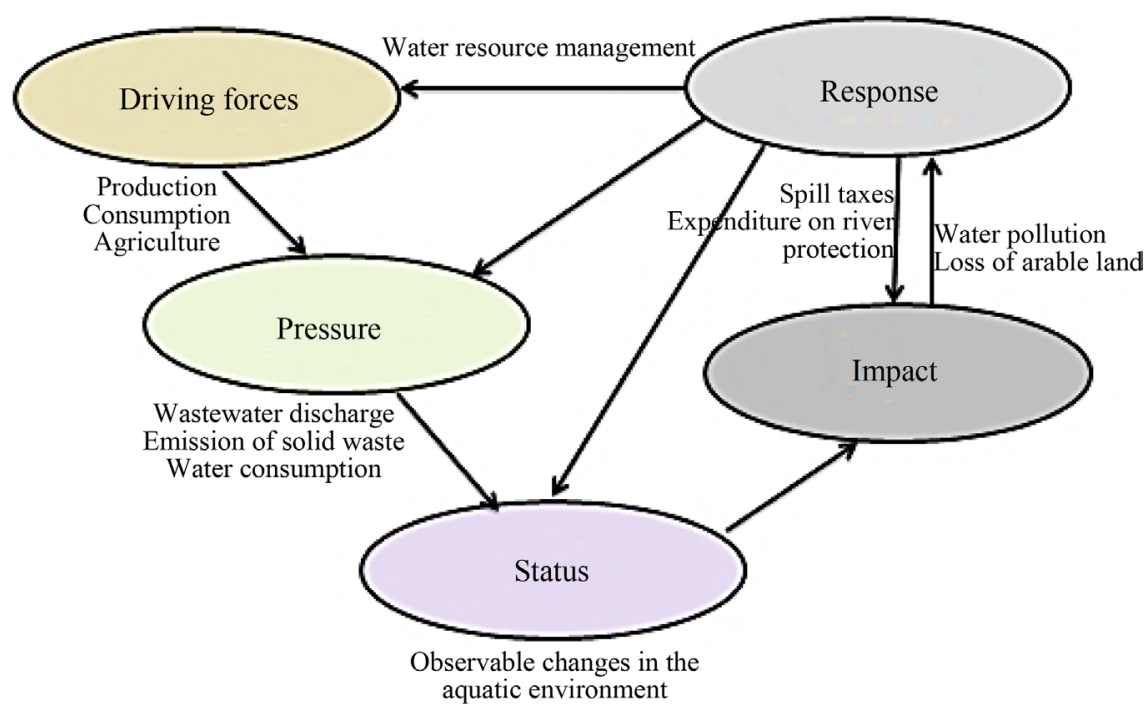

Figure 4. Logical framework for motive force-pressure-state-impact-response (DPSIR).

Table 5. Criteria for the assessment of water quality using the BMWP-PeA index, meaning and alert signal.

\begin{tabular}{ccccc}
\hline Class & Quality & BMWP-PA index & Significance & Alert Signal \\
\hline I & Good & $>120$ & Very clean water & \\
II & Acceptable & $61-100$ & Non-contaminated water & \\
III & Regular & $36-60$ & Moderately polluted waters & \\
IV & Bad & $16-35$ & Very polluted water & \\
V & Wretched & $<15$ & Severe contaminated water & \\
\hline
\end{tabular}

than not, the strongest driver indicator is population density, accompanied by different levels of developmental impulses; pressure (stressor) indicators are large-scale anthropogenic pressures which are exemplified by changes in land-use patterns and increase in air-water-soil pollution; state (exposure) indicators include aspects such as extents of organic/inorganic pollution of the environment actually being caused, and impact (ecological response) indicators include changes in biological community structure [76] [77] [78].

The most difficult challenge in index development is selecting and combining metrics in a manner that is complex enough to capture the dynamics of essential ecological processes but not so complex that its meaning is obscured [79]. Without a sound and obvious ecological foundation, an index will not be policy relevant and therefore difficult to use in the DPSIR systems. Once developed, such indices fall into three classes [80], based upon their complexity, information content and method of metric combination:

1) Univariate individual-species data, or community structure measures.

2) Multimetric indices, combining several measures of community response to stress into a single index. 
3) Multivariate methods describing the assemblage pattern.

\section{Multimetric Indices Based on Macroinvertebrates}

Next to fish, most IBIs have revolved round macroinvertebrates [81]-[86]. Macroinvertebrates are generally sedentary and it is relatively easier and simpler to sample them than fish. However, there are several disadvantages in using macroinvertebrates for IBIs. Firstly individuals are often variably distributed, causing problems in sampling and metric development [87] [88]. Secondly, a great deal of time and effort is associated with taxonomic identification prior to metric development [89]. Thirdly, high temporal variability of macroinvertebrates is a major factor limiting their use in ecological health indices [90]. Ephemoptera, Plecoptera and Trichoptera (EPT) have been commonly used in the metrics of macroinvertebrate-based IBIs. Percent Oligochaetes is another commonly used metric. Whereas the relative abundance of EPT decreases in disturbed water bodies, that of Oligochaetes, which is a pollution-tolerant taxon, increases.

\section{Conclusions}

The evaluation of water quality using physico-chemical parameters represents a monitoring approach based on stressors, whiles the same objective, when addressed through biota monitoring and represents a response-based monitoring approach. Both approaches have their distinctive features and the ideal course is to use both in an integrated way.

As environmental awareness increases and new scientific knowledge about global water quality emerges, the urgency, nature and scopes of the response (R) tend to change data needs, data analysis procedures and data interpretation needs. This makes it necessary to make adoptive changes in the indices, and integrate them into multimetric indices and even multivariate approaches.

As a result of events related to climate change, integrated spatial-temporal ecosystem models and indices are useful tools for ecosystem management. Multiple biotic integrity indices based on benthic macroinvertebrates have been developed in different parts of the world. In other regions the water quality is evaluated using the biodiversity indices of this benthic fauna considering relative abundance, Shannon index, Simpson index and Pielou uniformity together with the environmental variables.

\section{Conflicts of Interest}

The author declares no conflicts of interest regarding the publication of this paper.

\section{References}

[1] Cooper, M.J. and Uzarski, D.G. (2016) Invertebrates in Great Lakes Marshes. In: Batzer, D. and Boix, D., Eds., Invertebrates in Freshwater Wetlands. An International Perspective on Their Ecology, Springer International Publishing, Cham, 287-320. https://doi.org/10.1007/978-3-319-24978-0_9 
[2] Iwasaki, Y. and Ormerod, S.J. (2012) Estimating Safe Concentrations of Trace Metals from Inter-Continental Field Data on River Macroinvertebrates. Environmental Pollution, 166, 182-186. https://doi.org/10.1016/j.envpol.2012.03.028

[3] Guswa, A.J., Brauman, K.A., Brown, C., Hamel, P., Keeler, B.L. and Sayre, S.S. (2014) Ecosystem Services: Challenges and Opportunities for Hydrologic Modeling to Support Decision Making. Water Resources Research, 50, 4535-4544. https://doi.org/10.1002/2014WR015497

[4] Schäfer, R.B., Kühn, R.B., Malaj, E., König, A. and Gergs, R. (2016) Contribution of Organic Toxicants to Multiple Stress in River Ecosystems. Freshwater Biology, 61, 2116-2128. https://doi.org/10.1111/fwb.12811

[5] Prigent, C., Papa, F., Aires, F., Jimenez, C., Rossow, W.B. and Matthews, E. (2012) Changes in Land Surface Water Dynamics Since the 1990s and Relation to Population Pressure. Geophysical Research Letters, 39, L08403.

[6] Bendor, T.A (2009) A Dynamic Analysis of the Wetland Mitigation Process and Its Effects on No Net Loss Policy. Landscape and Urban Planning, 89, 17-27. https://doi.org/10.1016/j.landurbplan.2008.09.003

[7] Seitz, N.E., Westbrook, C.J. and Noble, B.F. (2011) Bringing Science into River Systems Cumulative Effects Assessment Practice. Environmental Impact Assessment Review, 31, 172-179. https://doi.org/10.1016/j.eiar.2010.08.001

[8] Goldberg, N. and Reiss, K.C. (2016) Accounting for Wetland Loss: Wetland Mitigation Trends in Northeast Florida 2006-2013. Wetlands, 36, 373-384. https://doi.org/10.1007/s13157-016-0749-4

[9] Hu, S., Niu, Z., Chen, Y., Li, L. and Zhang, H. (2017) Global Wetlands: Potential Distribution, Wetland Loss, and Status. Science of the Total Environment, 586, 319-327. https://doi.org/10.1016/j.scitotenv.2017.02.001

[10] Reiss, K.C., Hernandez, E. and Brown, M.T. (2014) Application of the Landscape Development Intensity (LDI) Index in Wetland Mitigation Banking. Ecological Modelling, 271, 83-89. https://doi.org/10.1016/j.ecolmodel.2013.04.017

[11] Clare, S. and Creed, I.F. (2014) Tracking Wetland Loss to Improve Evidence-Based Wetland Policy Learning and Decision Making. Wetlands Ecology and Management, 22, 235-245. https://doi.org/10.1007/s11273-013-9326-2

[12] Aazami, J., Esmaili Sari, A., Abdoli, A., Sohrabi, H. and Van Den Brink, P.J. (2015) Assessment of Ecological Quality of the Tajan River in Iran Using a Multimetric Macroinvertebrate Index and Species Traits. Environmental Management, 56, 260-269. https://doi.org/10.1007/s00267-015-0489-x

[13] Mitsch, W.J., et al. (2013) Wetlands, Carbon, and Climate Change. Landscape Ecology, 28, 583-597. https://doi.org/10.1007/s10980-012-9758-8

[14] Blasco, D. (2001) Wise Use of Wetlands. Journal of Environmental Law, 13, 293. https://doi.org/10.1093/jel/13.2.293

[15] Mostacero, L.J., Ramírez, V.R. and Mejía, C.F. (2008) Biological, Physical and Chemical Characterization of the High Andean Wetlands of La Libertad, Peru, 2008. Rebiol, 28, 91-98.

[16] Cano, A., et al. (2010) Flora and Vegetation of Cryoturbed Soils and Associated Habitats in the Cordillera Blanca, Ancash, Peru. Revista Peruana de Biología, 17, 95-103.

[17] Angulo-Pratolongo, F., Schulenberg, T.S. and Puse-Fernández, E.E. (2010) Birds of the Eten Wetlands, Lambayeque, Peru. Ecología Aplicada, 9, 71-82.

https://doi.org/10.21704/rea.v9i1-2.397 
[18] Amaro, L. and Goyoneche, G. (2010) Bird Nesting in the Los Pantanos de Villa Wildlife Refuge 2007-2009, Lima-Peru. The Biologist (Lima), 15, 155-171.

[19] Aponte, H., Ramírez, D. and Vargas, R. (2011) Wetlands of the Central Coast of Peru: Structure and Threats to Their Plant Communities. Ecología Aplicada, 10, 1-9.

[20] Iannacone, J. and Alvariño, L. (2007) Diversity and Abundance of Coastal Zooplanktonic Communities of the Wetland Pantanos de Villa, Lima, Peru. Gayana (Concepción), 71, 49-65. https://doi.org/10.4067/S0717-65382007000100006

[21] Paredes, C., Iannacone, J. and Alvariño, L. (2007) Invertebrate Biodiversity of the Puerto Viejo Wetlands, Lima, Peru. Neotropical Helminthology, 1, 21-30.

[22] Fuentealba, B. and Mejía, M. (2016) Ecological and Social Characterization of Andean Wetlands Huascarán Ecological and Social Characterization of Andean Wetlands Huascaran National. Aporte Santiaguino, 9, 303-316.

[23] Medrano, Y.R., Chupan, M.L. and Vila, B.M. (2012) Carbon Storage in Predominant Species of Flora in Chinchaycocha Carbon Storage in Predominant Species of Flora in Chinchaycocha Lake. Apuntes de Ciencia \& Sociedad, 2, 110-117. https://doi.org/10.18259/acs.2012013

[24] Gamarra, O. and Montoya, H. (2013) Floristic Composition, Physiognomic-Structural Description and Geographical Distribution of Macrophytes of the Los Milagros Wetland, Huánuco-Peru. Revista Investigación y Amazonía, 2, 12-19.

[25] Vizcarra, J.K. (2011) Confirmation of the Presence of Riparia riparia in the Wetlands of Ite, Southwestern Peru. The Biologist (Lima), 9, 123-125.

[26] Beltrán, D.F., et al. (2015) Water Quality of the Inner Puno Bay, Titicaca Lake, during Summer 2011. Revista Peruana de Biología, 22, 335-340.

[27] Roque, J.E. and Ramírez, E.K. (2008) Vascular Flora and Vegetation of Parinacochas Lake and Neighborhoods. Revista Peruana de Biología, 15, 61-72.

[28] Mamani, M. and Pari, D. (2014) Birds Diversity around the Stabilization Lake of Puno. Escuela de Postgrado, 5, 15.

[29] Otto, M. and Gibbons, R.E. (2017) Potential Effects of Projected Decrease in Annual Rainfall on Spatial Distribution of High Andean Wetlands in Southern Peru. Wetlands, 37, 647-659. https://doi.org/10.1007/s13157-017-0896-2

[30] Secretariat of the Ramsar Convention (2015) Wetlands: Why Take Care of Them? Ramsar Information Sheets. 1-2.

[31] Ministry of the Environment (2012) Descriptive Memory of the Map of Vegetal Coverage of Peru.

[32] Aven, T. and Renn, O. (2015) An Evaluation of the Treatment of Risk and Uncertainties in the IPCC Reports on Climate Change. Risk Analysis, 35, 701-712. https://doi.org/10.1111/risa.12298

[33] Swenson, J.J., et al. (2012) Plant and Animal Endemism in the Eastern Andean Slope: Challenges to Conservation. BMC Ecology, 12, 1. https://doi.org/10.1186/1472-6785-12-1

[34] Villarroel, E.K., Mollinedo, P.L.P., Domic, A.I., Capriles, J.M. and Espinoza, C. (2014) Local Management of Andean Wetlands in Sajama National Park, Bolivia. Mountain Research and Development, 34, 356-368. https://doi.org/10.1659/MRD-JOURNAL-D-14-00024.1

[35] Scholz, M. (2015) Wetlands for Water Pollution Control. 2nd Edition, In: The Book with the Previous Title Wetland Systems to Control Urban Runoff, Elsevier, Amsterdam. 
[36] Young, K.R. and Lipton, J.K. (2006) Adaptive Governance and Climate Change in the Tropical Highlands of Western South America. Climatic Change, 78, 63-102. https://doi.org/10.1007/s10584-006-9091-9

[37] Chevallier, P., Pouyaud, B., Suarez, W. and Condom, T. (2011) Climate Change Threats to Environment in the Tropical Andes: Glaciers and Water Resources. Regional Environmental Change, 11, 179-187. https://doi.org/10.1007/s10113-010-0177-6

[38] Naeem, S., Duffy, J.E. and Zavaleta E. (2012) The Functions of Biological Diversity in an Age of Extinction. Science, 336, 1401-1406. https://doi.org/10.1126/science.1215855

[39] Panigrahi, S., Acharya, B.C., Panigrahy, R.C., Nayak, B.K., Banarjee, K. and Sarkar, S.K. (2007) Anthropogenic Impact on Water Quality of Chilika Lagoon RAMSAR Site: A Statistical Approach. Wetlands Ecology and Management, 15, 113-126. https://doi.org/10.1007/s11273-006-9017-3

[40] Pizarro, H., et al. (2016) Impact of Multiple Anthropogenic Stressors on Freshwater: How Do Glyphosate and the Invasive Mussel Limnoperna fortunei Affect Microbial Communities and Water Quality? Ecotoxicology, 25, 56-68. https://doi.org/10.1007/s10646-015-1566-x

[41] Beasley, G. and Kneale, P.E. (2003) Investigating the Influence of Heavy Metals on Macro-Invertebrate Assemblages Using Partial Cononical Correspondence Analysis (pCCA). Hydrology and Earth System Sciences, 7, 221-233. https://doi.org/10.5194/hess-7-221-2003

[42] Engle, V.D. (2011) Estimating the Provision of Ecosystem Services by Gulf of Mexico Coastal Wetlands. Wetlands, 31, 179-193. https://doi.org/10.1007/s13157-010-0132-9

[43] Litchman, E., de Tezanos Pinto, P., Edwards, K.F., Klausmeier, C.A., Kremer, C.T. and Thomas, M.K. (2015) Global Biogeochemical Impacts of Phytoplankton: A Trait-Based Perspective. Journal of Ecology, 103, 1384-1396. https://doi.org/10.1111/1365-2745.12438

[44] Bharti, N. (2011) Water Quality Indices Used for Surface Water Vulnerability Assessment. International Journal of Environmental Sciences, 2, 154-173.

[45] Dinius, S.H. (1987) Design of an Index of Water Quality. JAWRA: Journal of the American Water Resources Association, 23, 833-843. https://doi.org/10.1111/j.1752-1688.1987.tb02959.x

[46] Abbasi T. and Abbasi, S.A. (2012) “Conventional” Indices for Determining Fitness of Waters for Different Uses. In: Abbasi, T. and Abbasi, S.A., Eds., Water Quality Indices, Elsevier, UK, 25-62. https://doi.org/10.1016/B978-0-444-54304-2.00003-8

[47] Boyacioglu, H. and Boyacioglu, H. (2007) Surface Water Quality Assessment by Environmetric Methods. Environmental Monitoring and Assessment, 131, 371-376. https://doi.org/10.1007/s10661-006-9482-4

[48] UNEP-WCMC (2008) State of the World's Protected Areas 2007: Annual Report on Global Conservation Progress. UNEP World Conservation Monitoring Centre Sponsored by the European Commission, 1-40.

[49] Tyagil, S., Sharma, B., Singh, P. and Dobhal, R. (2013) Water Quality Assessment in Terms of Water Quality Index. American Journal of Water Resources, 1, 34-38.

[50] Lumb, A., Sharma, T.C. and Bibeault, J.F. (2011) A Review of Genesis and Evolution of Water Quality Index (WQI) and Some Future Directions. Water Quality, Exposure and Health, 3, 11-24. https://doi.org/10.1007/s12403-011-0040-0 
[51] Brown, R., Mcclelland, R.M., Deininger, N.I. and Tozer, R.A. (1973) Validating the WQI. Presented at the National Meeting on Water Resources Engineering of the American Society for Civil Engineers, Environmental Indices Theory and Practice, Washington DC.

[52] Abbasi, T. and Abbasi, S.A. (2012) WQI-Generating Software and a WQI-Based Virtual Instrument. In: Abbasi, T. and Abbasi, S.A., Eds., Water Quality Indices, Elsevier, UK, 187-204. https://doi.org/10.1016/B978-0-444-54304-2.00011-7

[53] Council of the European Union (1991) Council Directive of 21 May 1991 Concerning Urban Waste Water Treatment (91/271/EEC). Official Journal of the European Union, 34, 1-16.

[54] De Rosemond, S., Duro, D.C. and Dubé, M. (2009) Comparative Analysis of Regional Water Quality in Canada Using the Water Quality Index. Environmental Monitoring and Assessment, 156, 223-240. https://doi.org/10.1007/s10661-008-0480-6

[55] Terrado, M., Barceló, D., Tauler, R., Borrell, E., De Campos, S. and Barceló, D. (2010) Surface-Water-Quality Indices for the Analysis of Data Generated by Automated Sampling Networks. TrAC Trends in Analytical Chemistry, 29, 40-52. https://doi.org/10.1016/j.trac.2009.10.001

[56] Said, A., Stevens, D.K. and Sehlke, G. (2004) An Innovative Index for Evaluating Water Quality in Streams. Environmental Management, 34, 406-414. https://doi.org/10.1007/s00267-004-0210-y

[57] Davis, W.S. and Simon, T.P. (1995) Biological Assessment and Criteria: Tools for Water Resource Planning and Decision Making. CRC Press, Boca Raton, FL.

[58] Hajkowicz, S. and Collins, K. (2007) A Review of Multiple Criteria Analysis for Water Resource Planning and Management. Water Resources Management, 21, 1553-1566. https://doi.org/10.1007/s11269-006-9112-5

[59] Lyons, J., Navarro-Pérez, S., Cochran, P.A., Santana, E. and Guzmán-Arroyo, M. (1995) Index of Biotic Integrity Based on Fish Assemblages for the Conservation of Streams and Rivers in West-Central Mexico. Conservation Biology, 9, 569-584. https://doi.org/10.1046/j.1523-1739.1995.09030569.x

[60] Borja, A., Franco, J. and Muxika, I. (2004) The Biotic Indices and the Water Framework Directive: The Required Consensus in the New Benthic Monitoring Tools. Marine Pollution Bulletin, 48, 405-408. https://doi.org/10.1016/j.marpolbul.2003.10.024

[61] Abbasi, T. and Abbasi, S.A. (2001) Water Quality Indices Based on Bioassessment: The Biotic Indices. Journal of Water and Health, 9, 330-348. https://doi.org/10.2166/wh.2011.133

[62] Pinto, R., Patrício, J., Baeta, A., Fath, B.D., Neto, J.M. and Marques, J.C. (2009) Review and Evaluation of Estuarine Biotic Indices to Assess Benthic Condition. Ecological Indicators, 9, 1-25. https://doi.org/10.1016/j.ecolind.2008.01.005

[63] Chessman, B.C. (1995) Rapid Assessment of Rivers Using Macroinvertebrates: A Procedure Based on Habitat-Specific Sampling, Family Level Identification and a Biotic Index. Australian Journal of Ecology, 20, 122-129. https://doi.org/10.1111/j.1442-9993.1995.tb00526.x

[64] Wimbaningrum, R., Indriyani, S., Retnaningdyah, C. and Arisoesilaningsih, E. (2016) Monitoring Water Quality Using Biotic Indices of Benthic Macroinvertebrates along Surfaces Water Ecosystems in Some Tourism Areas in East Java, Indonesia. Journal of Indonesian Tourism and Development Studies, 4, 81-90. https://doi.org/10.21776/ub.jitode.2016.004.02.06 
[65] Serrano, B.E., Grac, C., Berti-Equille, L. and Armienta, H.M. (2016) Potential Application of Macroinvertebrates Indices in Bioassessment of Mexican Streams. Ecological Indicators, 61, 558-567. https://doi.org/10.1016/j.ecolind.2015.10.007

[66] Sharifinia, M., Mahmoudifard, A., Imanpour Namin, J., Ramezanpour, Z. and Yap, C.K. (2016) Pollution Evaluation in the Shahrood River: Do Physico-Chemical and Macroinvertebrate-Based Indices Indicate Same Responses to Anthropogenic Activities? Chemosphere, 159, 584-594. https://doi.org/10.1016/j.chemosphere.2016.06.064

[67] Varnosfaderany, M.N., Ebrahimi, E., Mirghaffary, N. and Safyanian, A. (2010) Biological Assessment of the Zayandeh Rud River, Iran, Using Benthic Macroinvertebrates. Limnologica-Ecology and Management of Inland Waters, 40, 226-232. https://doi.org/10.1016/j.limno.2009.10.002

[68] Carter, J.L., Resh, V.H. and Hannaford, M.J. (2017) Macroinvertebrates as Biotic Indicators of Environmental Quality. In: Hauer, R. and Lamberti, G., Eds., Methods in Stream Ecology, 3rd Edition, Academic Press, UK, 293-318. https://doi.org/10.1016/B978-0-12-813047-6.00016-4

[69] Hawkes, H.A. (1998) Origin and Development of the Biological Monitoring Working Party Score System. Water Research, 32, 964-968. https://doi.org/10.1016/S0043-1354(97)00275-3

[70] Wyzga, B., et al. (2013) Interpretation of the Invertebrate-Based BMWP-PL Index in a Gravel-Bed River: Insight from the Polish Carpathians. Hydrobiologia, 712, 71-88. https://doi.org/10.1007/s10750-012-1280-0

[71] Paisley, M.F., Trigg, D.J. and Walley, W.J. (2014) Revision of the Biological Monitoring Working Party (BMWP) Score System: Derivation of Present-Only and Abundance-Related Scores from Field Data. River Research and Applications, 30, 887-904. https://doi.org/10.1002/rra.2686

[72] Ariella, K. and Moesriati, A. (2017) The Implementation of Biological Monitoring Working Party Average Score per Taxon (BMWP-ASPT) in a Water Quality Analysis at Kalibokor Drainage in Surabaya Region. AIP Conference Proceedings, 1908, Article ID: 030007.

[73] Custodio, M. and Amesquita, E. (2017) Evaluation of the Trophic State of the River Cunas by Means of Physical, Chemical and Biological Indexes, in Two Climatic Periods-Junín, Peru. Ambiente, 1, 26-36.

[74] Borja, Á., et al. (2006) The European Water Framework Directive and the DPSIR, a Methodological Approach to Assess the Risk of Failing to Achieve Good Ecological Status. Estuarine, Coastal and Shelf Science, 66, 84-96. https://doi.org/10.1016/j.ecss.2005.07.021

[75] Chainho, P., Chaves, M.L., Costa, J.L., Costa, M.J. and Dauer, D.M. (2008) Use of Multimetric Indices to Classify Estuaries with Different Hydromorphological Characteristics and Different Levels of Human Pressure. Marine Pollution Bulletin, 56, 1128-1137. https://doi.org/10.1016/j.marpolbul.2008.03.018

[76] Macedo, D.R., et al. (2016) Development of a Benthic Macroinvertebrate Multimetric Index (MMI) for Neotropical Savanna Headwater Streams. Ecological Indicators, 64, 132-141. https://doi.org/10.1016/j.ecolind.2015.12.019

[77] Donnelly, A., Jones, M., Mahony, T.O. and Byrne, G. (2007) Selecting Environmental Indicator for Use in Strategic Environmental Assessment. Environmental Impact Assessment Review, 27, 161-175. https://doi.org/10.1016/j.eiar.2006.10.006

[78] Niemeijer, D. and De Groot, R.S. (2008) A Conceptual Framework for Selecting Environmental Indicator Sets. Ecological Indicators, 8, 14-25. 
https://doi.org/10.1016/j.ecolind.2006.11.012

[79] Turnhout, E., Hisschemöller, M. and Eijsackers, H. (2007) Ecological Indicators: Between the Two Fires of Science and Policy. Ecological Indicators, 7, 215-228. https://doi.org/10.1016/j.ecolind.2005.12.003

[80] Tscherning, K., Helming, K., Krippner, B., Sieber, S. and Paloma, S.G. (2012) Does Research Applying the DPSIR Framework Support Decision Making? Land Use Policy, 29, 102-110. https://doi.org/10.1016/j.landusepol.2011.05.009

[81] Melo, S., Stenert, C., Dalzochio, M.S. and Maltchik, L. (2015) Development of a Multimetric Index Based on Aquatic Macroinvertebrate Communities to Assess Water Quality of Rice Fields in Southern Brazil. Hydrobiologia, 742, 1-14. https://doi.org/10.1007/s10750-014-1957-7

[82] Munné, A. and Prat, N. (2009) Use of Macroinvertebrate-Based Multimetric Indices for Water Quality Evaluation in Spanish Mediterranean Rivers: An Intercalibration Approach with the IBMWP Index. Hydrobiologia, 628, 203-225. https://doi.org/10.1007/s10750-009-9757-1

[83] Herman, M.R. and Nejadhashemi, A.P. (2015) A Review of Macroinvertebrate- and Fish-Based Stream Health Indices. Ecohydrology \& Hydrobiology, 15, 53-67. https://doi.org/10.1016/j.ecohyd.2015.04.001

[84] Moya, N., Hughes, R.M., Domínguez, E., Gibon, F.M., Goitia, E. and Oberdorff, T. (2011) Macroinvertebrate-Based Multimetric Predictive Models for Evaluating the Human Impact on Biotic Condition of Bolivian Streams. Ecological Indicators, 11, 840-847. https://doi.org/10.1016/j.ecolind.2010.10.012

[85] Jun, Y.C., Won, D.H., Lee, S.H., Kong, D.S. and Hwang, S.J. (2012) A Multimetric Benthic Macroinvertebrate Index for the Assessment of Stream Biotic Integrity in Korea. International Journal of Environmental Research and Public Health, 9, 3599-3628. https://doi.org/10.3390/ijerph9103599

[86] Baptista, D.F., Buss, D.F., Egler, M., Giovanelli, A., Silveira, M.P. and Nessimian, J.L. (2007) A Multimetric Index Based on Benthic Macroinvertebrates for Evaluation of Atlantic Forest Streams at Rio de Janeiro State, Brazil. Hydrobiologia, 575, 83-94. https://doi.org/10.1007/s10750-006-0286-x

[87] Wildsmith, M.D., Rose, T.H., Potter, I.C., Warwick, R.M. and Clarke, K.R. (2011) Benthic Macroinvertebrates as Indicators of Environmental Deterioration in a Large Microtidal Estuary. Marine Pollution Bulletin, 62, 525-538. https://doi.org/10.1016/j.marpolbul.2010.11.031

[88] Kenney, M.A., Sutton-Grier, A.E., Smith, R.F. and Gresens, S.E. (2009) Benthic Macroinvertebrates as Indicators of Water Quality: The Intersection of Science and Policy. Terrestrial Arthropod Reviews, 2, 99-128. https://doi.org/10.1163/187498209X12525675906077

[89] Basset, A., Sangiorgio, F. and Pinna, M. (2004) Monitoring with Benthic Macroinvertebrates: Advantages and Disadvantages of Body Size Descriptors. Aquatic Conservation: Marine and Freshwater Ecosystems, 14, S43-S58. https://doi.org/10.1002/aqc.649

[90] Buss, D.F. and Borges, E.L. (2008) Application of Rapid Bioassessment Protocols (RBP) for Benthic Macroinvertebrates in Brazil: Comparison between Sampling Techniques and Mesh Sizes. Neotropical Entomology, 37, 288-295. https://doi.org/10.1590/S1519-566X2008000300007 